\title{
Kísérleti Mütő és a Hepato-Pancreatico-Biliary (HPB) Surgical Research Center története a Semmelweis Egyetem I. sz. Sebészeti Klinikáján
}

\author{
FÜLÖP ANDRÁS, SZIJÁRTÓ ATTILA
}

Semmelweis Egyetem, I. sz. Sebészeti Klinika, Budapest

\begin{abstract}
A Semmelweis Egyetem I. sz. Sebészeti Klinika Kísérleti Mütője több évtizedes múltra tekint vissza. Alapításának pontos ideje nem ismert, annyi azonban a fellelhető adatok alapján elmondható, hogy az 1956-os forradalom idején már létezett. Visszaemlékezések alapján ekkoriban az átalakított, alagsori „kutyamütő” meghatározó szerepet játszott a harci sérültek ellátásában.
\end{abstract}

Az 50-es évekből kevés írásos emlék maradt fent. Később, a 60-as évek végétől a 80-as évek végéig a Kísérleti Mütő számos, a magyar sebésztársadalomban meghatározó szerepet betöltő vezető tudományos karrierjének kiindulópontjává vált, valódi tudományos mühellyé nőtte ki magát. Ez időből említést érdemel Kovács András nyulakon, kutyákon végzett orr-, valamint fülplasztikai kísérletei, illetve a 70-es években megindult szervtranszplantációs kutatások, melyekhez kapcsolódóan számos disszertáció, kandidátusi értekezés látott napvilágot. Többek közt 1974-ben Karácsonyi Sándor védte meg disszertációját az anhepatikus fázis fiziológiájából, majd 1975-ben Flautner Lajos „Kísérletes pancreas-transplantatio egyes kérdései” címmel, illetve 1976-ban Faller József „Átültetésre előkészített máj konzerválásával nyert tapasztalataink" címmel készített kandidátusi értekezést. Később Kupcsulik Péter végzett a Központi Orvostudományos Kutatóintézettel együttmüködésben enzimhisztokémia vizsgálatokon alapuló kutatásokat, eredményeit kandidátusi értekezés formájában 1977ben mutatta be. A 80 -as években az állatmütő már napi szinten, programszerủen müködött, és számos tudományos diákköri munkás is segítette a kutatásokat. Ekkoriban több sebészeti, gasztroenterológiai, illetve aneszteziológiai témát boncolgató értekezés született, nagyban hozzájárulva a Klinika és a kutatómühely hírnevének öregbítéséhez. A teljesség igénye nélkül kiemelendő Forgács András „Nyomás és pH-változások in vivo mérése és diagnosztikus értéke a tápcsatorna felső szakaszán”, Farkas András „Az umbilicalis kanülálás diagnosztikus és terápiás lehetőségei”, Kokas Péter „K-vitamin függő XI, XII alvadási faktor aktivitási szintjének változásai izoláltan perfundált ép és kóros patkánymájban, illetve Harsányi László és Bodoky György „A mesterséges táplálás új lehetőségeinek kísérletes és klinikai vizsgálata" címü dolgozata. A 80 -as évek végén, 90-es évek elején a sebésztechnika fejlödésével egyre nagyobb igény jelentkezett a sebészeti mütéttani képzés iránt is. Tihanyi Tibor vezetésével az ekkoriban újszerünek szá- mító laparoszkópos sebészeti beavatkozások bevezetése és oktatása szintén jelentős szerepet töltött be az állatmütő mindennapjaiban.

A 90-es évek elején a Kísérleti Mütő munkája átmenetileg leállt. Azonban 1997-ben Kupcsulik Péter témavezetése mellett Szijártó Attila és Hahn Oszkár mint orvostanhallgatók indították újra a kísérletes munkát, a máj microcirculatiojának és ischaemiás károsodásának témakörében önálló kutatási terv készült. Ennek eredményeként hosszú idő után újra, 2007-ben PhD-fokozat született „Az ischaemiás tolerancia növelésének lehetőségei a májsebészetben" Szijártó Attila jóvoltából. Ezt követően a klinikán folyó kísérletes sebészeti tevékenységek új lendületet vettek. Ekkor a labor érdeklődése elsősorban a különböző szervek ischaemiás-reperfúziós károsodására, illetve ennek mérséklésére irányult. Másfél évtized alatt több mint száz, kiemelkedő eredményeket (TDK, OTDK helyezések, Pro Sciencia aranyérmek) elérő tudományos diákköri munkát végzett hallgató gazdagította a labor életét. Mintegy egy évtized alatt, a témában további 8 doktori dolgozat született, melyek eredményeként Szijártó Attila 2016-ban a Magyar Tudományos Akadémia doktora címet is elnyerte „Az ischaemiás kórállapotok befolyásolhatósága az idő függvényében" címü tanulmányával. A lelkes tudományos diákkörös és doktrandusz hallgatók szép számmal választották a sebészeti pályát hivatásuknak. Az iskolateremtő mühely számos külföldi (Amszterdam, Hamburg, Aachen, Kyoto, Boston) tanulmányútra is alkalmat adott a laborban dolgozóknak.

Jelenleg a labor fö kutatási területe a különbözö májvolumen-manipulációs technikák, májregeneráció vizsgálata. A véna portae okklúziós eljárások patofiziológiai hátterét vizsgáló kutatásokból számos, nemzetközileg is magasan rangsorolt tudományos közlemény, két Bolyai-ösztöndíj és további 3 doktori értekezés született az elmúlt néhány évben. A Kísérleti Mütő tevékenységét jelzi a közel 70 közlemény, valamint az 500-at meghaladó idézettség.

Az országosan és nemzetközi összevetésben is kiemelkedő kutató tevékenység a máj, a hasnyálmirigy, valamint az epeutak betegségeivel kapcsolatos kutatások fókuszában mindig e szervek kórélettani, sebészeti anatómiai viszonyai, új sebészi eljárások modellezése, bevezetése álltak. E mindennapi gyakorlatba könnyen átültethető alapkutatások - mai terminológiával élve tehát transzlációs ku- 
tatások - nem lennének kivitelezhetők évtizedes múltra visszatekintő kollaborációk nélkül. Kiemelendő, hogy az eredményes nemzetközi kapcsolatok eredményeként került megrendezésre 2014-ben Budapesten a European Society for Surgical Research 49. kongresszus Szijártó Attila elnökletével. Ennek a folyamatos és folyamatosan megújuló, bővülő szakmai együttmüködésen nyugvó munkának továbbfejlesztése céljából született meg 2015-ben egy új szervezeti forma, a Hepato-Pancreatico-Biliary (HPB) Surgical Research Center. A munkacsoport célja és feladata az önálló klinikai és kísérletes vizsgálatok támoga- tása mellett a témával foglalkozó különböző társszakmák, hazai és külföldi szakemberek felkutatása, tevékenységük összekapcsolása. A munkacsoport nevéhez köthető a 2017es European Digestive Surgery - 11th EDS Postgraduate Course megrendezése, illetve a 2019-ben megrendezésre kerülő „Colorectalis májmetastasisok komplex kezelése” és a 2020-ban megrendezendő „Hepatocellularis carcinoma komplex kezelése" névre hallgató konszenzus konferencia, amelyet várhatóan a jövőben további, hasonló szakmai kongresszusok követnek majd.

A cikk a Creative Commons Attribution 4.0 International License (https://creativecommons.org/licenses/by/4.0/) feltételei szerint publikált Open Access közlemény, melynek szellemében a cikk bármilyen médiumban szabadon felhasználható, megosztható és újraközölhetö, feltéve, hogy az eredeti szerző és a közlés helye, illetve a CC License linkje és az esetlegesen végrehajtott módosítások feltüntetésre kerülnek. (SID_1) 